\title{
FAKTOR DETERMINAN DALAM \\ PEMILIHAN BIDANG KEAHLIAN TEKNIK MESIN DI SEKOLAH MENENGAH KEJURUAN
}

\author{
Dwi Rahdyanta \\ Pendidikan Teknik Mesin FT UNY \\ teknik@uny.ac.id
}

\begin{abstract}
Abstrak
Tujuan penelitian ini adalah untuk memperoleh gambaran faktor situasional, factor, pilihan bidang keahlian teknik mesin dan determinasi faktor situasional dan faktor psikologis dalam pemilihan bidang keahlian teknik mesin di SMK di Daerah Istimewa Yogyakarta. Penelitian yang dilakukan merupakan penelitian korelasional dan bersifat ex-post facto Penelitian dilakukan di SMK Kelompok Teknologi dan Rekayasa pada Bidang Keahlian Teknik Mesin negeri dan swasta di wilayah Daerah Istimewa Yogyakarta. Data dianalisis dengan analisis deskriptif, analisis regresi dan analisis jalur. Hasil analisis deskriptif menunjukkan bahwa 1) skor untuk faktor situasional termasuk dalam kategori tinggi, skor untuk faktor psikologis termasuk dalam kategori tinggi, dan skor pilihan bidang keahlian teknik mesin di SMK termasuk dalam kategori tinggi, 2) ada pengaruh faktor situasional dan psikologis terhadap pemilihan bidang keahlian teknik mesin SMK di Y ogkarta.

Kata kunci: faktor situasional, faktor psikdogis, deteminas bidang keahlian tdknik mesin SMK
\end{abstract}




\title{
DETERMINANT FACTOR IN THE CHOISE OF THE MECHANICAL ENGINEERING EXPERTISE PROGRAM IN VOCATIONAL HIGH SCHOOLS
}

\author{
Dwi Rahdyanta \\ Pendidikan Teknik Mesin FT UNY \\ teknik@uny.ac.id
}

\begin{abstract}
This study aims to describe situational and psychological factors, the choice of the mechanical engineering skill program, and determinations of situational and psychological factors on the choice of the mechanical engineering skill program in VHSs in the Yogyakarta Special Territory. This was a correlational study which was ex post facto in nature. It was conducted in public and private VHSs belonging to the technology and engineering cluster in the Mechanical Engineering Skill Program in the Yogyakarta Special Territory. The data were analyzed using the descriptive analysis, regression analysis, and path analysis. The results of the descriptive analysis show that 1) the scores of situational factors are in the high category, those of psychological factors are in the high category, and that of the choice of the mechanical engineering skill program in VHSs is in the high category, and 2) there are effects of situational and psychological factors on the choice of the mechanical engineering skill program in VHSs in Yogyakarta.
\end{abstract}

Keywords: deteminant fadors, Medhanical Eng்nemingSkill Progam 


\section{Pendahuluan}

Sesuai dengan Undang-Undang Nomor 20 Tahun 2003 tentang Sistim Pendidikan Nasional, setelah siswa SMP/MTs lulus memiliki dua alternatif pilihan untuk melanjutkan pendidikan formal, yaitu pendidikan menengah umum dan pendidikan menengah kejuruan. Pendidikan menengah umum berbentuk Sekolah Menengah Atas (SMA) dan Madrasah Aliyah (MA), sedangkan pendidikan menengah kejuruan berbentuk Sekolah Menengah Kejuruan (SMK) dan Madrasah Aliyah Kejuruan (MAK).

Dalam hal pilihan untuk melanjutkan pendidikannya ke SMK, para siswa kelas IX SMP/MTs perlu mendapatkan perhatian yang serius dari berbagai pihak agar dalam menentukan pilihan bidang keahlian yang ada di SMK mereka tidak keliru. Hal ini sangat beralasan mengingat ada 121 kompetensi keahlian yang ditawarkan di SMK sebagaimana yang telah ditetapkan dalam spektrum keahlian pendidikan menengah kejuruan. (Keputusan Direktur Jenderal Manajemen Pendidikan Dasar dan Menengah Nomor 25/ C/ kep/ mn/ 2008, Tanggal 22 Agustus 2008).

Pilihan bidang keahlian pada hakekatnya adalah proses perpaduan antara kebutuhan-kebutuhan, harapan-harapan, sumber-sumber pribadi individu, dan tuntutan ekonomi (Super, 1957: 56; Vroom, 1979). Lebih lanjut London (1973: 74) mengemukakan bahwa pilihan bidang keahlian merupakan perpaduan antara minat, kemampuan, nilai-nilai, peluang, harapan dan adanya keterbatasan-keterbatasan dalam realita kehidupan. Untuk itulah perlu adanya informasi yang intensif dari sekolah maupun orang tua kepada para siswa SMP/ MTs terkait dengan pemilihan bidang keahlian di SMK.

Permasalahan yang terjadi dalam pemilihan bidang keahlian di SMK oleh para lulusan siswa SMP/ MTs, secara garis besar dapat dikelompokkan menjadi tiga, yaitu permasalahan yang terkait dengan bimbingan orang tua dan guru, pengaruh sosial masyarakat, dan permasalahan yang terkait dengan aspek psikologis siswa.

Mengingat begitu luasnya spektrum bidang keahlian di SMK, maka penelitian ini difokuskan pada pemilihan salah satu bidang keahlian yang ada di SMK yaitu bidang keahlian teknik mesin. Adapun faktor-faktor 
determinan dalam pemilihan bidang keahlian teknik mesin di SMK untuk faktor eksternal/ lingkungan dibatasi pada variabel lingkungan keluarga, lingkungan sekolah asal, dan lingkungan sosial masyarakat, sedangkan untuk faktor internal/psikologis dibatasi pada variabel penguasaan informasi, pemahaman diri, dan sikap siswa pada SMK.

Teori-teori tentang pilihan karir atau bidang keahlian telah banyak dikemukakan oleh para ahli, antara lain Super, Tiedeman, O sipow, Victor Vroom, dan Ginzberg. Secara ringkas, teori tentang pilihan karir atau pekerjaan dari para ahli tersebut akan dideskripsikan dan dijadikan referensi untuk mengungkap lebih jauh masalah pemilihan bidang keahlian di SMK oleh para lulusan siswa SMP/ MTs.

Pemilihan bidang keahlian hakekatnya adalah proses perpaduan antara kebutuhan-kebutuhan, sumber-sumber pribadi individu, tuntutan ekonomi, dan kondisi sosial budaya. Lebih lanjut juga disebutkan bahwa perkembangan vokasional seseorang hakekatnya merupakan interaksi antara perilaku, sikap, ambisi dan nilai-nilai individu dengan faktor-faktor sosial di sekitarnya (Super, 1957: 56).

Tiedeman \& O'Hara (1963:35) mengemukakan bahwa pengambilan keputusan merupakan masalah yang pelik dalam tahapan perkembangan vokasional seseorang. Mereka mengemukakan bahwa ada hubungan antara kepribadian dan bidang kejuruan pada proses pilihan bidang kejuruan seseorang. Perkembangan kepribadian seseorang pada dasarnya merupakan proses mental seseorang sebagai konsekuensi keterlibatannya, baik dalam keberbedaaan maupun kebersamaan di masyarakat. Tiedeman menggunakan istilah identitas diri (epidantity) dalam mendesknipsikan kepribadian seseorang dalam kehidupan sosial kemasyarakatan. Identitas diri terbentuk karena adanya interaksi antara tiga faktor yaitu: kondisi biologis individu, psikologis dan sosial atau budaya tempat individu berada atau lingkungan so sial budaya di sekitarnya.

Pemilihan bidang keahlian merupakan suatu proses yang stabil yang terjadi pada periode tertentu dan menupakan perpaduan antara harapan dan berbagai kemungkinan (Osipow, 1996: 29-30). Lebih lanjut disebutkan bahwa ada tiga tahapan dalam proses pemilihan bidang keahlian/ vokasional seseorang yaitu: tahap fantasi, tentatip dan realistik. 
Tahap fantasi umumnya terjadi pada anak usia sekitar 6 -11 tahun. Pada masa ini anak mulai menunjukkan adanya perhatian terhadap kerja, namun anak-anak belum dapat mengakses kemampuan atau kesempatan dan keterbatasan realita. Mereka berkeyakinan dapat menjadi apapun yang mereka inginkan. Orientasi pilihan mereka masih berubah-ubah. Tahap tentatif terjadi pada anak usia 11 - 17 tahun. Pada masa ini anak-anak mulai menyadari adanya permasalahan yang dihadapi berkaitan dengan karir atau keahlian masa depan mereka. Mereka mulai menimbang-nimbang potensi diri yang mereka miliki.

Menurut Vroom (1979), bahwa seseorang akan melalukan suatu pilihan secara sadar di antara berbagai alternatif pilihan yang tujuannya adalah untuk memaksimalkan kesenangan dan meminimalkan rasa sakit. Teori ini sering juga disebut teori harapan.

Menurut teori ini bahwa seseorang yang telah menetapkan tujuan atau pilihan yang telah diambil dapat termotivasi untuk mewujudkannya jika mereka percaya bahwa ada korelasi positif antara upaya dan kinerja, adanya pemenuhan imbalan sebagaimana yang diinginkan, penghargaan/ hadiah dari prestasi yang diperoleh dan keinginan yang kuat untuk memenuhi kebutuhan, sehingga membuat waktu kerja menjadi sangat berharga.

Berdasarkan pendapat dari Ginzberg yang dikemukakan oleh Isaacson (1977: 46) bahwa dalam proses pemilihan karir atau keahlian terdapat empat variabel yang mempengaruhinya, yaitu: reality factars, ecurational proess emotional factors dan pessonal values Reelity factors menyangkut respon seseorang terhadap kondisi lingkungan di sekitamya yang memaksa diri orang tersebut untuk membuat keputusan berkaitan dengan karimya. Educational proess berkaitan dengan kualitas dan kuantitas pendidikan yang diperoleh seseorang yang memungkinkan membuka wawasan orang tersebut untuk menentukan pilihan karir. Emotional factors adalah hal-hal yang menyangkut aspek-aspek kepribadian. Pesonal values adalah aspek-aspek nilai yang melekat pada diri seseorang yang ikut mempengaruhi dalam memilih karir.

D ani berbagai teori dan rumusan di atas dapat disimpulkan bahwa faktor-faktor yang berpengaruh dalam pemilihan bidang keahlian atau 
karier seseorang yaitu: emctional factors (minat, perasaan, harapan/ dampak, dan pendirian), pessonal factors (kepribadian, karakter, dan nilai-nilai), educational factors (kemampuan kognitif, kemampuan psikomotorik, pengalaman pendidikan dan latihan), dan reality fadors (daya tampung/ peluang yang ada, biaya, dan persyaratan pendukungnya).

Pemilihan bidang keahlian merupakan psychdogical individual amareness of the dgetive world in its reation to the saff (Moris, 1982: 355). Lebih lanjut disebutkan bahwa perkembangan vokasional seseorang hakekatnya merupakan interaksi antara perilaku, sikap, ambisi dan nilai-nilai individu dengan faktor-faktor sosial di sekitamya (Super, 1957: 56). Jadi, pemilihan bidang keahlian merupakan proses psikologi dari diri seseorang untuk menentukan sikap yang tepat dan benar dalam menghadapi sesuatu obyek.

Karakter atau kepribadian seseorang akan mempengaruhi orang tersebut dalam menyikapi adanya berbagai ragam keahlian atau pekerjaan yang ada di masyarakat (Holland, 1973: 88). Hal ini berarti bahwa setiap orang akan memilih karir atau pekerjaan tertentu sesuai dengan karakternya masing-masing. Berdasarkan teori Holland tersebut orang akan melihat kedalam dirinya sendiri (pemahaman diri) untuk mengukur cocok tidaknya suatu karir atau pekerjaan dengan dirinya. Hal ini berarti pemahaman diri (sdf knoukedg) merupakan salah satu faktor penting yang berpengaruh dalam pemilihan bidang kejuruan. Sedangkan menurut Victor Vroom (1979), bahwa seseorang akan memilih suatu bidang kejuruan atau pekerjaan tertentu jika mereka memiliki keyakinan dan harapan bahwa pekerjaan atau bidang keahlian yang dipilihnya akan membawa keberhasilan maka ia akan berusaha dengan sekuat tenaga untuk mendapatkan bidang keahlian atau pekerjaan tersebut.

Dalam menentukan pilihan suatu bidang keahlian juga dipengaruhi oleh faktor dari luar diri individu atau faktor ekternal. Faktor eksternal adalah faktor di luar diri individu yang juga sering disebut sebagai faktor situasional. Lingkungan pada hakekatnya adalah segala aspek atau penomena fisik dan sosial yang mempengaruhi organisme seseorang (Chaplin, 1979: 175). Penomena fisik dan sosial ini menjadi sumber informasi yang dapat diperoleh seseorang melalui penglihatan, pendengaran, penciuman dan rasa. Informasi inilah yang kemudian 
menjadikan seseorang memiliki wawasan, pengetahuan dan pemahaman tentang sesuatu objek.

Menurut Lenski \& Lenski dalam Piotr Sztompka (2010: 3), bahwa segala aspek kehidupan manusia baik yang menyangkut: seni, ilmu, agama, moral, budaya, pendidikan, politik, ekonomi, maupun kehidupan keluarga akan sangat dipengaruhi oleh situasi kondisi lingkungan di mana ia berada. Sedangkan menurut Mohammad Ali (2009: 98), bahwa perbedaan lingkungan dapat menimbulkan perbedaan sikap pada individu, yang secara psikologis dapat dipelajari melalui tiga cara yaitu: (1) meniru orang yang lebih berprestasi dalam bidang tertentu, (2) mengkombinasikan pengalaman, dan (3) pengalaman khusus dengan emosional yang mendalam. Lebih lanjut disebutkan bahwa tingkah laku manusia mengikuti pola atau tata aturan tertentu menurut cara yang telah berpola baku di lingkungannya (Ary G unawan, 2010: 21).

D ari uraian di atas dapat ditarik kesimpulan bahwa determinan dalam pemilihan bidang keahlian teknik mesin di SMK merupakan proses mental yang dipengaruhi oleh faktor internal (individu/ psikologis), maupun faktor ekstemal (lingkungan/ situasional). Faktor internal dalam penelitian ini dikelompokkan menjadi tiga variabel utama yaitu variabel sikap siswa terhadap SMK, penguasaan informasi, dan pemahaman diri siswa. Sedangkan faktor ekstemal dapat dikelompokkan menjadi tiga variabel utama, yaitu variabel lingkungan keluarga, lingkungan sekolah dan lingkungan sosial masyarakat.

Tujuan Penelitian ini adalah untuk memperoleh gambaran faktor situasional, factor, pilihan bidang keahlian teknik mesin dan determinasi faktor situasional dan faktor psikologis dalam pemilihan bidang keahlian teknik mesin di SMK di D aerah Istimewa Y ogyakarta.

\section{Metode Penelitian}

Penelitian yang dilakukan merupakan penelitian korelasional, bertujuan untuk merumuskan faktor-faktor yang berpengaruh terhadap pemilihan bidang keahlian teknik mesin di SMK oleh para lulusan siswa SMP/MTs di DIY. Pada penelitian ini tidak ada pengendalian atau 
perlakuan terhadap variabel bebas secara langsung karena peristiwa telah terjadi, sehingga penelitian ini termasuk penelitian ex-post facto(Ary, Jacobs \& Razavieh, 1982:282; Gay, 1981:197; Issac, 1981:50).

Populasi dalam penelitian ini adalah adalah siswa kelas X Sekolah Menengah Kejuruan (SMK) Kelompok Keahlian Teknologi dan Industri, Bidang Keahlian Teknik Mesin di Daerah Istimewa Yogyakarta yang berjumlah 1095 orang siswa (http:// www.pendidikan-diy.go.id). Jumlah sampel ditentukan dengan mendasarkan pada penentuan ukuran sampel menurut Krejcie dan Morgan (Issac, 1981: 192) menggunakan taraf kesalahan 5\%. Berdasarkan hasil perhitungan, diperoleh ukuran sampel sebesar 285 responden (pembulatan). Untuk mengantisipasi angket maupun data yang tidak dapat terolah, jumlah sampel ditambah sebesar $5 \%$. D engan demikian sampel minimal yang digunakan dalam penelitian ini adalah sebesar: $285+(5 \%$ x 285 $)=300$ responden (pembulatan). Teknik sampling yang digunakan adalah propational randomsamplingsehingga jumlah sampel kelompok dihitung berdasarkan jumlah populasi masing-masing kelompok.

Teknik pengumpulan data dalam penelitian ini adalah survey dengan menggunakan alat pengumpul data berupa angket, lembar pengamatan, dan dokumentasi. Validitas instrumen dalam penelitian ini meliputi validitas isi (content validity) dan validitas konstruk (construct validity). Untuk mengetahui validitas isi instrumen dilakukan melalui expet judgement dengan teknik D elphi, dalam hal ini melibatkan tujuh orang ahli (expet judgement). Validitas konstruk dibuktikan dengan menggunakan analisis faktor konfirmatori untuk mengetahui apakah butir-butir instrumen tersebut cocok untuk menaksir unsur-unsur yang terdapat dalam konstruk yang telah ditetapkan (Ary, Jacobs Razavieh, 1982:289-291; Coakes \& Stead, 1996:123). Perhitungan reliabilitas menggunakan kaidah Cronbach Alpha (Fernandes, 1984:61).

Teknik analisis data dalam penelitian ini meliputi dua analisis yaitu analisis deskriptif dan analisis inferensial (uji hipotesis) dengan terlebih dahulu dilakukan uji persyaratan analisis (normalitas, linieritas, homoskedastisitas, dan multikolinieritas). Adapun tata hubung antar variabel dalam penelitian ini ditampilkan pada $\mathrm{G}$ ambar 1 berikut ini. 


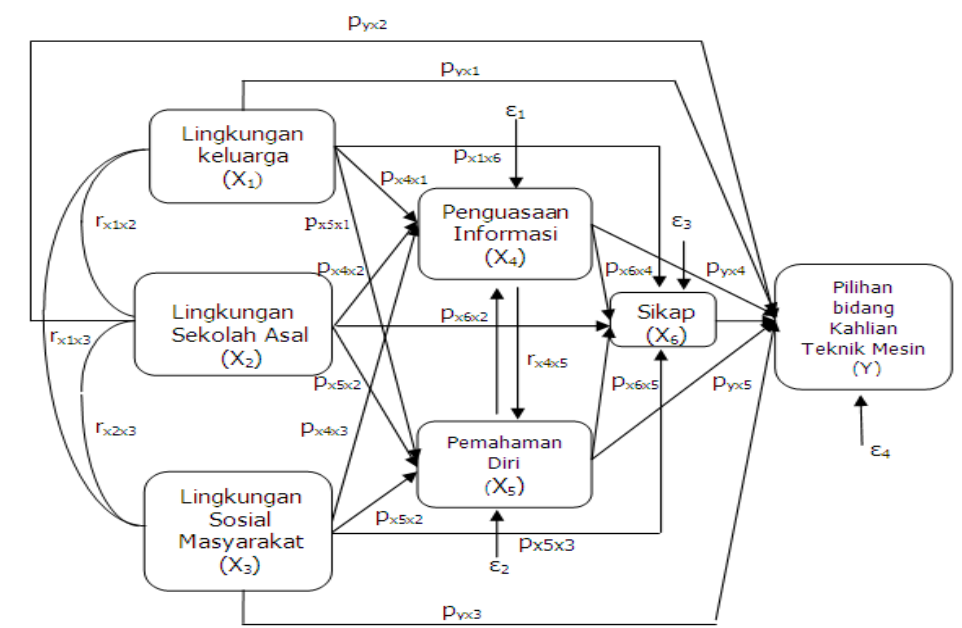

Gambar 1. Tatahubung Antar Variabel

\section{Hasil Penelitian}

Hasil analisis deskriptif menunjukkan bahwa lingkungan keluarga, lingkungan sekolah asal, lingkungan sosial masyarakat, penguasaan informasi, pemahaman diri, sikap siswa dan pilihan bidang keahlian teknik mesin di SMK oleh para lulusan siswa SMP/ MTs termasuk dalam kategori tinggi. Adapun pencapaian skor tanggapan siswa dari skor tertinggi yang telah ditetapkan secara berurutan masing-masing adalah sebesar. 73,9\%; $74,1 \% ; 69,3 \% ; 73,5 \% ; 80,3 \% ; 83,6 \%$, dan $81 \%$.

Untuk memenuhi persyaratan-persyaratan analisis dalam penelitian ini dilakukan uji normalitas, uji linieritas, uji homoskedastisitas, dan uji multikolinieritas. Hasil uji normalitas menunjukkan bahwa distribusi skor dan distribusi residual semua variabel dalam penelitian ini memenuhi syarat normalitas. Hal ini dapat dilihat dari indikator sebagai berikut: a) skor masing-masing variabel terdistribusi mendekati kurve normal, b) dilihat dari normal probaility pldt tampak bahwa distribusi data masing-masing variabel berada di sekitar garis diagonal dan mengikuti arah garis diagonal,

Faktor-FaktorDeteminan dalamPemilihanBidangKeahlian - 191 
dan c) kemiringan (skewness) masing-masing variabel terletak diantara $-0,5$ sampai $+0,5$.

Berdasarkan hasil uji linieritas, dapat diketahui bahwa nilai $F_{\text {hitung }}$ untuk masing-masing pasangan, pada kolom linieitylebih besar dar $\mathrm{F}$ tabel. Hal ini menunjukkan bahwa arah garis regresi semua pasangan berarti. Sedangkan jika dilihat nilai dan signifikansi $F$ pada kolom dev.fromlinieity, semuanya memenuhi persyaratan linieritas $\left(\mathrm{F}_{\text {hitung }}<\mathrm{F}_{\text {tabel }}\right.$ atau sig $\left.>0,05\right)$.

Berdasarkan pencermatan scatterpdt dapat diketahui bahwa distribusi skor (berupa titik-titik) semua variabel terikat dalam persamaan regresi tidak membentuk pola tertentu dan menyebar secara acak di sekitar angka nol pada sumbu Y. Hasil uji Park menunjukkan bahwa regresi logaritma variabel bebas terhadap logaritma nilai kuadrat residual dari semua pasangan regresi menunjukkan nilai $F$ yang tidak signifikan $(\mathrm{Sig}>0,05)$. Berdasarkan dua pertimbangan tersebut dapat disimpulkan bahwa persamaan-persamaan regresi yang ditetapkan dalam penelitian ini semuanya memenuhi syarat homoskedastisitas.

Berdasarkan hasil analisis uji multikolinieritas dapat diketahui bahwa koefisien korelasi ( $\mathrm{r}$ product moment) semua variabel bebas dalam penelitian ini berada di bawah 0,85; nilai tderancelebih besar dari 0,1; dan tidak ada nilai VIF di atas 10. D engan demikian dapat disimpulkan bahwa tidak terdapat bukti adanya multikolinieritas yang serius antar variabel bebas.

Selanjutnya dilakukan uji hipotesis, dengan hasil sebagai berikut:

a. Ada pengaruh signifikan lingkungan keluarga $\left(\mathrm{X}_{1}\right)$, lingkungan sekolah asal $\left(\mathrm{X}_{2}\right)$, dan lingkungan sosial masyarakat $\left(\mathrm{X}_{3}\right)$ terhadap penguasaan informasi $\left(\mathrm{X}_{4}\right)$; $(\mathrm{F}=103,98 ; \mathrm{p}<0,05)$. Koefisien determinasi $\left(\mathrm{R}^{2}\right)=$ 0,513 menunjukkan sumbangan tiga variabel tersebut sebesar 51,3\%.

b. Ada pengaruh signifikan lingkungan keluarga $\left(\mathrm{X}_{1}\right)$, lingkungan sekolah asal $\left(\mathrm{X}_{2}\right)$, dan lingkungan sosial masyarakat $\left(\mathrm{X}_{3}\right)$ terhadap pemahaman diri $\left(\mathrm{X}_{5}\right) ;(\mathrm{F}=45,216 ; \mathrm{p}<0,05)$. Koefisien determinasi $\left(\mathrm{R}^{2}\right)=0,314$ menunjukkan sumbangan tiga variabel tersebut sebesar $31,4 \%$.

c. Ada pengaruh signifikan lingkungan orang tua $\left(\mathrm{X}_{1}\right)$, lingkungan sekolah asal $\left(\mathrm{X}_{3}\right)$, dan lingkungan sosial masyarakat $\left(\mathrm{X}_{3}\right)$, penguasaan informasi $\left(\mathrm{X}_{4}\right)$, dan pemahaman diri siswa $\left(\mathrm{X}_{5}\right)$ terhadap sikap siswa 
pada SMK $\left(\mathrm{X}_{6}\right) ;(\mathrm{F}=55,00 ; \mathrm{p}<0,05)$. D ari hasil analisis juga dapat diketahui Koefisien determinasi $\left(\mathrm{R}^{2}\right)=0,483$. Hal ini berarti bahwa sumbangan lima variabel tersebut sebesar 48,3\%.

d. Ada pengaruh signifikan lingkungan orang tua $\left(\mathrm{X}_{1}\right)$, lingkungan sekolah asal $\left(\mathrm{X}_{2}\right)$, dan lingkungan sosial masyarakat $\left(\mathrm{X}_{3}\right)$, penguasaan informasi $\left(\mathrm{X}_{4}\right)$, pemahaman diri siswa $\left(\mathrm{X}_{5}\right)$, dan sikap siswa $\left(\mathrm{X}_{6}\right)$ terhadap pemilihan bidang keahlian teknik mesin di SMK (Y); $(F=56,815 ; p<0,05)$. Koefisien determinasi $\left(R^{2}\right)=0,538$ menunjukkan sumbangan enam variabel tersebut sebesar $53,8 \%$.

Model hubungan kausal empirik yang memuat bobot regresi $(\beta)$ atau koefisien jalur model lengkap (full modd) disajikan pada G ambar 2.

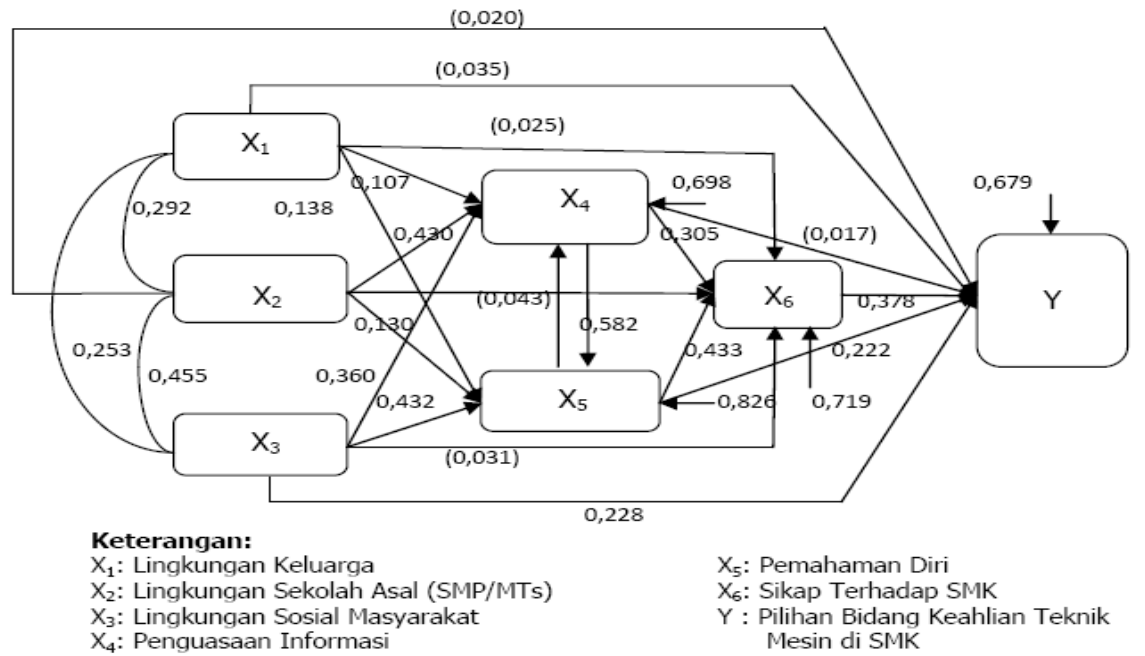

Gambar 2. Model Hubungan Kausal Empirik (Full Modd)

Hasil uji signifikansi koefisien jalur dilanjutkan dengan regresi model stepvise dan menghilangkan koefisien jalur yang tidak signifikan $(<0,05)$, disajikan pada Tabel 11. Berdasarkan perhitungan besarnya pengaruh langsung dan tidak langsung tersebut dapat diketahui:

a. Pengaruh langsung lingkungan keluarga terhadap pemilihan bidang keahlian teknik mesin di SMK tidak signifikan, dan pengaruh tidak

Faktor-FaktorDeteminandalamPemilihen BidangKeahlian - 193 


\section{Jumal Penditian danEvaluas Penddikan}

langsung melalui penguasaan informasi dan sikap tidak signifikan, namun pengaruh tidak langsung melalui pemahaman diri dan sikap siswa signifikan.

b. Pengaruh langsung lingkungan sekolah terhadap pemilihan bidang keahlian di SMK tidak signifikan. Namun pengaruh atidak langsung melalui pemahaman diri dan sikap siswa signifikan, dan pengaruh tak langsung melalui penguasaan informasi dan sikap siswa signifikan.

c. Pengaruh langsung lingkungan sosial masyarakat terhadap pemilihan bidang keahlian di SMK signifikan, dan pengaruh tak langsung melalui pemahaman diri dan sikap siswa signifikan. Hal ini berarti bahwa lingkungan sosial masyarakat memiliki peran yang sangat penting dalam pemilihan bidang keahlian teknik mesin di SMK.

Tabel 11. Rangkuman Hasil Analisis Jalur

\begin{tabular}{|c|c|c|c|c|c|c|c|c|c|}
\hline \multicolumn{2}{|c|}{ Variabel } & \multirow{2}{*}{$\begin{array}{c}\text { Efek } \\
\text { Langsung }\end{array}$} & \multicolumn{3}{|c|}{$\begin{array}{c}\text { Efek tak Langsung } \\
\text { Melalui } \\
\end{array}$} & \multirow{2}{*}{$\begin{array}{l}\text { Total } \\
\text { ETL }\end{array}$} & \multirow{2}{*}{$\begin{array}{l}\text { Efek } \\
\text { Total }\end{array}$} & \multirow{2}{*}{$\begin{array}{c}\text { Efek } \\
\text { Non- } \\
\text { Kausal }\end{array}$} & \multirow[t]{2}{*}{ Korelasi } \\
\hline Terikat & Bebas & & $\mathrm{X}_{4}$ & $\mathrm{X}_{5}$ & $\mathrm{X}_{6}$ & & & & \\
\hline \multirow{3}{*}{$\mathrm{X} 4$} & $\mathrm{X}_{1}$ & 0,187 & - & - & - & - & 0,187 & 0.137 & 0,324 \\
\hline & $\mathrm{X}_{2}$ & 0,430 & - & - & - & - & 0,430 & 0.195 & 0,625 \\
\hline & $\mathrm{X}_{3}$ & 0,360 & - & - & - & - & 0,360 & 0.223 & 0,583 \\
\hline \multirow{3}{*}{ X 5} & $\mathrm{X}_{1}$ & 0,138 & - & - & - & - & 0,138 & 0.147 & 0,285 \\
\hline & $\mathrm{X}_{2}$ & 0,130 & - & - & - & - & 0,130 & 0.237 & 0,367 \\
\hline & $\mathrm{X}_{3}$ & 0,432 & - & - & - & - & 0,432 & 0.094 & 0,526 \\
\hline \multirow{5}{*}{$\mathrm{X} 6$} & $\mathrm{X}_{1}$ & - & 0,063 & 0,061 & - & 0,124 & 0,124 & 0.107 & 0,231 \\
\hline & $\mathrm{X}_{2}$ & - & 0,146 & 0,057 & - & 0,203 & 0,203 & 0.198 & 0,401 \\
\hline & $\mathrm{X}_{3}$ & - & 0,122 & 0,190 & - & 0,312 & 0,312 & 0.136 & 0,448 \\
\hline & $\mathrm{X}_{4}$ & 0,340 & - & - & - & - & 0,340 & 0.255 & 0,595 \\
\hline & $\mathrm{X}_{5}$ & 0,439 & - & - & - & - & 0,439 & 0.197 & 0,636 \\
\hline \multirow{6}{*}{$\mathrm{Y}$} & $\mathrm{X}_{1}$ & - & 0,025 & 0,057 & - & 0,093 & 0,175 & 0.099 & 0,274 \\
\hline & $\mathrm{X}_{2}$ & - & 0,057 & 0,053 & - & 0,103 & 0,213 & 0.159 & 0,372 \\
\hline & $\mathrm{X}_{3}$ & 0,245 & 0,048 & 0,177 & - & 0,287 & 0,532 & 0.013 & 0,545 \\
\hline & $\mathrm{X}_{4}$ & - & - & - & 0,133 & 0,133 & 0,133 & 0.400 & 0,533 \\
\hline & $\mathrm{X}_{5}$ & 0,238 & - & - & 0,171 & 0,171 & 0,409 & 0.206 & 0,615 \\
\hline & $\mathrm{X}_{6}$ & 0,390 & - & - & - & - & 0,390 & 0.261 & 0,651 \\
\hline
\end{tabular}

194 - Jumal PenditiandanEvaluas Penddikan Edisi D ies Natalis ke-48 UNY 


\section{Kesimpulan}

Hasil analisis deskniptif menunjukkan bahwa faktor situasional (lingkungan keluarga, lingkungan sekolah asal, lingkungan sosial masyarakat), maupun faktor psikologis dari siswa (penguasaan informasi, pemahaman diri, sikap siswa) dan pilihan bidang keahlian teknik mesin di SMK oleh para lulusan siswa SMP/ MTs termasuk dalam kategori tinggi. Hal ini menunjukkan bahwa baik faktor situasional maupun faktor psikologis dari lulusan siswa SMP/MTs menunjukkan gambaran yang positif dalam pemilihan bidang keahlian teknik mesin di SMK. Adapun pencapaian skor tanggapan siswa dari skor tertinggi yang telah ditetapkan secara berurutan masing-masing adalah sebesar: 73,9\%; 74,1\%; 69,3\%; $73,5 \% ; 80,3 \% ; 83,6 \%$, dan $81 \%$.

Hasil analisis regresi ganda menunjukkan bahwa ada pengaruh signifikan lingkungan keluarga, lingkungan sekolah asal, lingkungan sosial masyarakat, penguasaan informasi, pemahaman diri, dan sikap siswa terhadap pemilihan bidang keahlian teknik mesin di SMK dengan sumbangan sebesar 53,8\%.

Berdasarkan koefisien determinasi parsialnya, sikap siswa mempunyai sumbangan terbesar terhadap pemilihan bidang keahlian teknik mesin di SMK (13,8\%), diikuti secara berurutan lingkungan sosial masyarakat $(6,3 \%)$, pemahaman diri $(5 \%)$, penguasaan informasi $(4,6 \%)$, lingkungan keluarga $(3,2 \%)$, dan lingkungan sekolah asal $(0,7 \%)$. Dengan demikian sikap siswa memiliki pengaruh yang lebih dominan dalam menentukan pemilihan bidang keahlian teknik mesin di SMK.

A dapu hasil analisis jalur sebagai beikut:

1) Pengaruh langsung lingkungan keluarga terhadap pemilihan bidang keahlian teknik mesin di SMK tidak signifikan. Namun pengaruh tidak langsung melalui pemahaman diri dan sikap siswa signifikan.

2) Pengaruh langsung lingkungan sekolah terhadap pemilihan bidang keahlian teknik mesin di SMK tidak signifikan. Namun pengaruh tidak langsung melalui pemahaman diri dan sikap siswa signifikan. D emikian juga pengaruh tidak langsung melalui penguasaan informasi dan sikap siswa signifikan. 
3) Pengaruh langsung lingkungan sosial masyarakat terhadap pemilihan bidang keahlian di SMK signifikan. Demikian juga pengaruh tak langsung melalui pemahaman diri dan sikap siswa signifikan.

4) Faktor psikologis berupa pemahaman diri dan sikap siswa memiliki pengaruh signifikan baik secara langsung maupun tidak langsung dalam menentukan pemilihan bidang keahlian teknik mesin di SMK, sedangkan penguasaan informasi tidak memberikan pengaruh langsung terhadap pemilihan bidang keahlian teknik mesin di SMK namun berperan dalam meningkatkan sikap siswa untuk kemudian mempengaruhi dalam pemilihan bidang keahlian teknik mesin di SMK bagi siswa lulusan SMP/ MTs.

Hasil analisis jalur menunjukkan peran penting variabel pemahaman diri dan sikap siswa terhadap SMK dalam menjelaskan pengaruh berbagai faktor situasional (lingkungan orang tua, lingkungan sekolah asal, lingkungan sosial masyarakat) terhadap pemilihan bidang keahlian teknik mesin di SMK. Disamping itu penguasaan informasi juga menunjukkan peran signifikan terhadap peningkatan ketepatan dalam pemilihan bidang keahlian teknik mesin di SMK melalui sikap siswa terhadap SMK. Oleh karena itu sangat beralasan untuk lebih memberikan prioritas dalam pengembangan ketiga faktor psikologis tersebut dalam upaya meningkatkan peran aspek situasional (lingkungan orang tua, lingkungan sekolah, lingkungan sosial masyarakat) dalam meningkatkan ketepatan dalam pemilihan bidang keahlian teknik mesin di SMK.

\section{Saran}

Terkait dengan hasil penelitian ini, disarankan:

a. Perlu dilakukan pemberdayaan pada orang tua siswa khususnya yang terkait dengan wawasan mengenai sekolah lanjutan yang dalam hal ini mengenai program-program yang ada di SMK maupun mengenai dunia kerja.

b. Pihak sekolah asal (SMP/MTs) perlu meningkatkan program bimbingan kejuruan, penanaman jiwa wirausaha, mendatangkan praktisi industri ke sekolah untuk ceramah, kunjungan siswa ke dunia 
usaha/ industri, dan pengenalan berbagai jenis pekerjaan maupun bidang keahlian yang ada di masyarakat yang disisipkan dalam mata pelajaran yang terkait. Hal tersebut dimaksudkan agar para siswa memiliki wawasan yang luas mengenai keduniakerjaan dan dapat menanamkan pada siswa sikap disiplin, ulet, jujur, mandiri, dan senang bekerja keras.

c. Pemerintah dalam hal ini Kementerian Pendidikan Nasional perlu lebih mengefektifkan pencitraan SMK di masyarakat baik melalui media cetak maupun elektronik.

d. Para siswa SMP/MTs perlu selalu didorong untuk dapat meningkatkan kapasitas diri khususnya yang terkait dengan kemampuan penguasaan informasi, pemahaman diri dan pengembangan sikap dengan penyediaan berbagai akses media informasi dan pemberian bimbingan kejuruan yang lebih intensif lagi.

\section{Daftar Pustaka}

Ary, D onald., Jacobs \& Razavieh. (1982). Introduction to rearch in education New York: Holt, Rinehart and Winston.

Chapplin, J.P. (2005). Dicianary of psydhdogy. New York: D ell Publishing Co., Inc.

Coakes, S.J., \& Steed, L.G. (1996). SPSS for Windons Analysis withat anguish New York: John Wiley \& Sons.

D epdiknas. (2008). Keputusan Dirkktur Jenderal Manajemen Pendidikan Dasar dan Menengah Nomm. 25/ C/ Ke/ m/ 2008, Tanggal 22 Agusus 2008, tentangSpaktrumKeahlian Pada Pendidkan Menengah Kejunuan

Fernandez, H.J.X. (1984). Testingand Measurement Jakarta: D epdikbud.

G ay. (1981). Educational London : Charles E. merril Publishing Co.

G unawan Ary, H. (2010). Sosidog pendidikan Jakarta : Rineka Cipta.

Herrick, Michael J. (10 Januari 2000). Assessment of student achievement and leaming. what would Dewey say? A recent interview with John 
Jumal Penditian danEvaluas Pendidkan

Dewey. Jaumal of Vocational and Tehnical Education Vo. 13, No.2, pp.18-32. Diambil pada tanggal 10 April 2009 dari http:// www.yahoo.com.

Holland, J.L. (1973). Makingvoational dhice A theory of careers Engleo owds: Prentice Hal, Inc.

Hurlock, E.B. (1980). Devepmental psyddogy, a lifespan approadh (Terjemahan Istiwidayati \& Soedjarwo). New York : McG raw-Hill Inc. (Buku asli diterbitkan 1980).

Isaac, Stephen \& Michael, William B., (1981). Handbook in rearch and evaluation California: Edits Publisher.

Isaacson, Lee., E . (1977). Career infomation in cunsding and teaching Boston: Allyn and Bacon, Inc.

Lembaran Negara Republik Indonesia. (2003). UndangUndang Republik Indonesia Nomr 20 Tahm 2003 tentang Sistem Pendidikan Nasional. Jakarta: Sekretariat Negara.

London, H.H., (1973). Priniples and techniques of vocational guidance Columbus, O hio: Charless E. Merrill Publishing Co.

Mohammad Ali, \& Mohammad Asrori. (2009). Psikdog Remaja Jakarta: PT. Bumi Aksara.

Morris, William. (1982). TheAmerican heritace dictionary. Boston: Haughton Mifflin Company.

O sipow, Samuel H., \& Fitzgerald, Louise F., (1996). Theries of career dedapment ( $4^{\text {th }} E d$.). Massachusset: Allyn $\&$ Bacon.

Super, D .E. (1957). ThePsychdogy of Career. New York: Harper \& Brothers.

Sztompka, Piotr. (2010). Sosidog penubahan sosial. Jakarta: Prenada Media.

Thompson, J.F. (1973). Foundations of vocational exucation, Social and philosqphical coneqpts New Jersey: Prentice Hall.

198 - Jumal PenditiandanEvaluasi Penddikan E disi D ies Natalis ke-48 UNY 
Jumal Penditian dan Evaluasi Pendidkan

Tiedeman, D.V., \& O' Hara, R.P. (1963). Caree dedepment : Chice and adjustment. Princenton, N.J.: College Entrance Examination Board.

Vroom, Victor H. (1979). Managementandmativation New Y ork:

Winkel, W.S., \& Sri Hastuti. (2006). Psikdog pendidkandanealuasi bdajar. Jakarta: Gramedia. 